\title{
The Dominant Nodes Index in Shortest Paths (DNISP) as a Local Measure of Source Looking for the Target in Complex Networks
}

\author{
https://doi.org/10.3991/ijim.v14i19.15153 \\ Hussein L. Hasan $(\bowtie)$ \\ University of Babylon, Babylon, Iraq \\ hus loia@uobabylon.edu.iq \\ Salah A. Albermany \\ University of Kufa, Najaf, Iraq
}

\begin{abstract}
When there are multiple alternate shortest paths between any two nodes in a complex network, there is a need to know details about the content of the paths and the dominance of the nodes within it, this need comes to maximize, control and speed of the information diffusion. This paper discusses the creation of a new special measure as a local scale for any $\mathrm{X}$ node in the network. This measure will give each neighbor of the node $\mathrm{X}$ a domination value to access the rest of the network, in other words any nodes included in the shortest path $(\mathrm{X}, \mathrm{Y})$ will be given a control value, taking into account the existence of more than one shortest path between $(X, Y)$. Such a measure is called a DNISP, which stands for Dominant Nodes Index in Shortest Paths. The X-node needs to examine all shortest paths that connect it with any other nodes across the ones that are directly associated with it. This measure provides an insight into how information flows between nodes according to dominant values with each node
\end{abstract}

Keywords-Communication, shortest paths, information diffusion, centralities, neighbor Nodes

\section{Introduction}

Complex networks consist of nodes, such as actors, countries, companies, groups, roads, emails and cities, which interface with each other inside an association or society [1]. These links produce social connections that are referred to relationships as social networks [2]. A relationship may start with an unimportant associate and may be communicated in numerous ways, contingent upon the pertinent subject and setting [3].

There are likewise intellectual or passionate connections that are set up on the premise of components, such as affirmation, kinship, regard, and restrictiveness [4]. A relationship can similarly be built up and characterized regarding activities [5], like selling, purchasing, talking, supporting, and traveling [6]. Those performing actors 
inside a social relationship influence one another, which keeps up or augments those relationship [7]. The point when people select a specific item alternately creates new technology [8], they frequently take mandatory advice starting with others which would more work together towards a regular objective, as opposed to choosing acting separately [9]. Therefore, it will be important with comprehend social participants' impacts looking into each other [10]. However, the suggested viewpoint needs to be restricted to actors' singular aspects as opposed to the actor's associations [11]. Consequently, an individual is assumed to be introverted or reserved, and unaffected by relationships with other participants within the network [12], where changes in the situation or relationship are not taken into estimation [13]. This assumption has only been common for relationships in social networks with large numbers of performing and influential individuals, as well as more complex and varying relationships among individuals [14]. This assumption is owed to the absence of interest, the ratio of the information available, and the relationship complexity [15].

This paper will provide a look at local node properties, where the shortest paths between the intended node and all other nodes within the network will be explored. It will suggest an explanation of how data flows between a given node and the rest of the nodes in the network, what paths control the data flow for that node, and which nodes control more paths for that node. Thus, each existing node will have index of nodes that are directly or indirectly associated. The index will reflect certain ratios of control for those nodes over the data flow of that node.

\section{Related Works}

The related prior work is discussed from three different perspectives, information diffusion in social media and networks, shortest path, and decentralized search.

\subsection{Social diffusion analysis}

The subject of analysis of diffusion of social information is still the main concern of many researchers in several different scientific disciplines, disease propagation, economic, physics, epidemiology, and social science [16]. There has been cumulative work on anticipating and modeling information diffusion paths in various social networks that are useful for diverse applications of prevent and control rumor [17], systems of recommendations, systems of online advertising, and prediction of user behavior [18]. In a simple and uncomplicated work, the authors offer a solution to the problem of optimization by choosing the most influential nodes to serve as a seed for wide diffusion within the network [19]. Whereas in a more developed work, studies how to place a post of roads and paths within the network so as to penetrate into distant paths. Another more complex work and summarizes the tests on diffusion models [20], where propagations are often found to occur through a powerful data catalyst that encourages data to propagate in taking different paths. Although most research highlights a built-in solution to the problem of selecting a sub-group to 
characterize its general characteristics, there are a number of determinants in the context of establishing general rules for the diffusion of data in complex networks [21]:

- Value of Information- There is an important feature in the diffusion of information, which is related to the extent of the spread of information within complex networks in social media platforms. This characteristic is the value of information, reliance only on the structure of abstract relationships between network components does not reflect the activity of relationships, in other words a node could overcome the number of relationships with other nodes but at the same time be idle.

- User Affairs - User-specific information may include marital status, age, geographic location, and preferences. Such data is often wholly or partially ignored in most researches, as it is directly related to the user's state and willingness to interact with other users.

\subsection{Shortest path}

It is important to find the right people or entities for sharing events such as holding romantic meetings, scientific, sporting events, or opening new channels between companies and institutions that are interested in a given subject, product, research, idea or service [22]. In order to fulfill the task of finding them worthy of attention, perhaps a simple strategy is to nominate communication bodies. These can exploit and employ shorter paths between nodes to achieve access to the best favorites [4]. The principle of "friends of friends" can be employed and build an excellent network of suggestions and find shorter paths among the nodes based on the interrelationships between them and the amount of contribution to each other [23]. Sometimes the path is too short between the node itself and the desired node, or there are several short paths, which provide good flexibility to choose between them. In a large community area or more broadly across one or more countries, shared factors such as language, customs, institutions or commercial companies may act on its borders [24] . Ref. [12] has shown that there can be a small circle of people between every two people in these communities in the so- called "small world". This principle was applied on the United States as an example among residents in the state of Newark, where it was found, and there are several close links within the community network which may reach an average of four [25]. The rate of close links between any two people may also be at an average of 4.1 between states [3]. Certainly, with the increase and momentum of users, the rate could be much lower [26]. For example, if the average person's links are taken up to $\mathrm{L}=1500$ ones, at a second level we expect to get for acquaintances (friends of friends) L1=225*104 links. Subsequently, being L2 = $50625 * 108$ links, it may take a maximum of two mediators to reach the entire population of the United States and potentially one sufficient mediator [27]. In a previous research, the average number of contacts per person was 300 links, giving about 4 intermediaries to reach everyone in the United States community. There may be an opportunity to gain access to as many acquaintances through dense links between nodes, as explained in, a node connection to a dense network improves shorter access to acquaintances [28]. 


\subsection{Decentralized search}

When a graph $\mathrm{G}$ is given, node s wants to send a message to node $t$, It is passed along the edges of the graph, so that the least number of steps have been taken to reach t-node, s only knows information about its neighbors and the location of $t$, does not know information about the neighbors of anyone else except itself. Each vertex $\mathrm{s}$ in graph $\mathrm{G}$ has its local information, such as a vertex $\mathrm{s}$ in given step has information of [4]:

- Recognize set of local nodes $v$ contacts among all the vertices

- Detect location of the target $\mathrm{t}$

- The locations and long-range contacts of all the vertices who were part of this message chain.

Given this information, $\mathrm{s}$ must choose one of its contacts $\mathrm{v}$ to pass on the message.

\section{The Proposed Method}

When we try to explain the transmission of data between network nodes, especially if this network is complicated, and why did the data decide to go this way and did not follow another alternative path? We will not find a convincing explanation. Many of researches have attempted to identify the shortest path between nodes in complex networks, but what about was inside the bath was forgotten or ignored. For example, assuming that within a complex network there are more than one short path that connects the $\mathrm{s}$ node and the $\mathrm{t}$ node, and that the data will take the shortest route (although it is not necessary to take the shortest route in all cases). So, there are varying proportions of the control of these nodes in the flow of data from s to t, a particular node may prevail in the contribution, this is attributed to several factors, including links or the location of this node. Most researches do not pay attention to how data is transmitted or tracked between nodes. Yet, in this research it is attempted to give a close-up picture of how paths are controlled by nodes located within the paths, giving a visualization of how strategies are developed, for example "going viral", immunization, influence maximization. Important symbols with their details in a Table 1.

Table 1. Important of symbols

\begin{tabular}{|c|l|l|}
\hline Name of Symbol & \multicolumn{1}{|c|}{ Illustration } & \multicolumn{1}{|c|}{ Description } \\
\hline$G$ & An unweighted and undirected network & $\mathrm{G}=(\mathrm{s}, \mathrm{E})$ \\
\hline $\mathrm{S}$ & Set of nodes in network & $\mathrm{S}=\{\mathrm{s} 1, \mathrm{~s} 2, \ldots, \mathrm{sn}\}$ \\
\hline $\mathrm{N}$ & number of set $\mathrm{S}$ & $\mathrm{n}:=|\mathrm{S}|$ \\
\hline $\mathrm{E}$ & Set of Edges & $\mathrm{E}=\{\mathrm{e} 12, \mathrm{e} 13,$, eij $\}, \mathrm{i} \neq \mathrm{j}$ \\
\hline $\mathrm{M}$ & number of set $\mathrm{E}$ & $\mathrm{m}:=|\mathrm{E}|$ \\
\hline
\end{tabular}

\subsection{Steps of (DNISP)}

1. Input: undirected graph $\mathrm{g}=(\mathrm{v}, \mathrm{e})$, source vertex $\mathrm{s}$, target vertex $\mathrm{t}$. 
2. Process:

i. Apply Decentralized Search for each vertex as source in first loop and for same source with each vertex in second loop.

ii. For each pair (s, t) we apply

a) Find all vertexes $\mathrm{L} 1=\{\mathrm{X} 1, \mathrm{X} 2, \ldots \mathrm{Xk}\}$ in shortest paths(could be more than one Shortest paths) from $\mathrm{s}$ to $\mathrm{t}$

b) Exception s, t and vertex that directly connect s modified L1 by L2

c) Divided 1 over the rest of vertexes in L2, where each vertex takes one credit.

d) In case of repeating the same vertex in L2, it takes half a credit for each time.

e) The steps c \& d can be formed in more details, the formal for computation function of $f(x)=$ shares of each node from credits, we need to create list L3 related to list L2 which contain the value of occurrence of each node that is $(V x)$, then creates L4 which contains values of $f(x)$ :

$$
\forall x \in \mathbf{L 4} f(x)=\left\{\begin{array}{r}
1, V x=1, x \in \mathbf{L 3} \\
1+((V x-1) * 1 / 2), V x>1, x \in \mathbf{L} \mathbf{3}
\end{array}\right.
$$

Where: $f(x)=$ shares for each node $\mathrm{x}$ from credits in list $\mathrm{L}_{4}, V_{x}=$ value of occurrence of each node $\mathrm{x}$ in list $\mathrm{L}_{3}$.

$$
D c=\frac{1}{\sum_{i=0}^{n} f(x)}, x \in \mathbf{L} \mathbf{4}
$$

Where: Dc $=$ Value of one credit, $\mathrm{n}=$ number of unique nodes in list L3, $\mathrm{f}(\mathrm{x})=$ shares for each node $\mathrm{x}$ from credits in list L4.

(a) Output: The values in list L5 that contains $k(x)$ :

$$
\forall x \in \mathbf{L 5} k(x)=D c * f(x), x \in \mathbf{L 4}
$$

Where: $\mathrm{k}(\mathrm{x})=$ represent the contribution each vertex in shortest paths between $(\mathrm{s}, \mathrm{t})$ that allow or control of information flow between $(s, t), D c=$ Value of one credit, $f(x)$ $=$ shares for each node $\mathrm{x}$ from credits in list L4.

\section{$4 \quad$ Apply (DNISP) in Example}

In the paper, use the network model shown in Fig 1. To apply (DNISP) steps. 


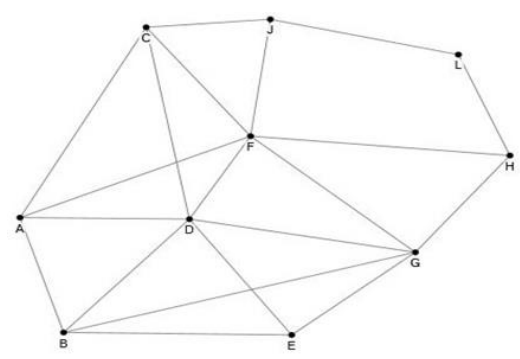

Fig. 1. Network of nodes

In Table 2 (DNISP) will be applied between a couple of nodes (source, target) to find the upper control nodes in the paths as well as the marginal nodes in the multiple paths between each pair.

Table 2. Apply (DNISP)

\begin{tabular}{|c|c|c|c|c|}
\hline Pair & \begin{tabular}{|c|}
$\begin{array}{c}\text { Number of shortest } \\
\text { paths }\end{array}$ \\
\end{tabular} & $\begin{array}{c}\text { Number of edges in } \\
\text { path }\end{array}$ & Detail of paths & Values of (DNISP) \\
\hline$(\mathrm{A}, \mathrm{J})$ & 2 & 2 & $\begin{array}{l}(\mathrm{A}, \mathrm{C}, \mathrm{J}) \\
(\mathrm{A}, \mathrm{F}, \mathrm{J})\end{array}$ & $\begin{array}{l}\mathrm{C}=0.5 \\
\mathrm{~F}=0.5\end{array}$ \\
\hline$(\mathrm{A}, \mathrm{G})$ & 3 & 2 & $\begin{array}{l}(\mathrm{A}, \mathrm{D}, \mathrm{G}) \\
(\mathrm{A}, \mathrm{B}, \mathrm{G}) \\
(\mathrm{A}, \mathrm{F}, \mathrm{G})\end{array}$ & $\begin{array}{l}\mathrm{D}=0.33 \\
\mathrm{~B}=0.33 \\
\mathrm{~F}=0.33\end{array}$ \\
\hline$(\mathrm{A}, \mathrm{I})$ & 3 & 3 & $\begin{array}{l}\text { (A, C, J, I) } \\
(\mathrm{A}, \mathrm{F}, \mathrm{J}, \mathrm{I}) \\
(\mathrm{A}, \mathrm{F}, \mathrm{H}, \mathrm{I})\end{array}$ & $\begin{array}{l}\mathrm{C}=0.2 \\
\mathrm{~F}=0.3 \\
\mathrm{~J}=0.3 \\
\mathrm{H}=0.2\end{array}$ \\
\hline$(\mathrm{A}, \mathrm{H})$ & 1 & 2 & $(\mathrm{~A}, \mathrm{~F}, \mathrm{H})$ & $\mathrm{F}=1$ \\
\hline$(\mathrm{A}, \mathrm{E})$ & 2 & 2 & $\begin{array}{l}(\mathrm{A}, \mathrm{B}, \mathrm{E}) \\
(\mathrm{A}, \mathrm{D}, \mathrm{E})\end{array}$ & $\begin{array}{l}\mathrm{B}=0.5 \\
\mathrm{D}=0.5\end{array}$ \\
\hline$(\mathrm{B}, \mathrm{C})$ & 2 & 2 & $\begin{array}{l}(\mathrm{B}, \mathrm{A}, \mathrm{C}) \\
(\mathrm{B}, \mathrm{D}, \mathrm{C})\end{array}$ & $\begin{array}{l}\mathrm{A}=0.5 \\
\mathrm{D}=0.5\end{array}$ \\
\hline$(\mathrm{B}, \mathrm{F})$ & 3 & 2 & $\begin{array}{l}(\mathrm{B}, \mathrm{D}, \mathrm{F}) \\
(\mathrm{B}, \mathrm{A}, \mathrm{F}) \\
(\mathrm{B}, \mathrm{G}, \mathrm{F}) \\
\end{array}$ & $\begin{array}{l}\mathrm{D}=0.33 \\
\mathrm{~A}=0.33 \\
\mathrm{G}=0.33\end{array}$ \\
\hline$(\mathrm{B}, \mathrm{H})$ & 1 & 2 & $(\mathrm{~B}, \mathrm{G}, \mathrm{H})$ & $\mathrm{G}=1$ \\
\hline$(\mathrm{B}, \mathrm{I})$ & 1 & 3 & $(\mathrm{~B}, \mathrm{G}, \mathrm{H}, \mathrm{I})$ & $\begin{array}{l}G=0.5 \\
H=0.5\end{array}$ \\
\hline$(\mathrm{B}, \mathrm{J})$ & 5 & 3 & $\begin{array}{l}(\mathrm{B}, \mathrm{A}, \mathrm{C}, \mathrm{J}) \\
(\mathrm{B}, \mathrm{A}, \mathrm{F}, \mathrm{J}) \\
(\mathrm{B}, \mathrm{D}, \mathrm{F}, \mathrm{J}) \\
(\mathrm{B}, \mathrm{G}, \mathrm{F}, \mathrm{J}) \\
(\mathrm{B}, \mathrm{D}, \mathrm{C}, \mathrm{J})\end{array}$ & $\begin{array}{l}\mathrm{A}=0.2 \\
\mathrm{C}=0.2 \\
\mathrm{D}=0.2 \\
\mathrm{~F}=0.26 \\
\mathrm{G}=0.13\end{array}$ \\
\hline$(\mathrm{E}, \mathrm{H})$ & 1 & 2 & $(\mathrm{E}, \mathrm{G}, \mathrm{H})$ & $\mathrm{G}=1$ \\
\hline$(\mathrm{E}, \mathrm{I})$ & 1 & 3 & (E, G, H, I) & $\begin{array}{l}\mathrm{G}=0.5 \\
\mathrm{H}=0.5\end{array}$ \\
\hline$(\mathrm{E}, \mathrm{J})$ & 3 & 3 & $\begin{array}{l}(\mathrm{E}, \mathrm{D}, \mathrm{C}, \mathrm{J}) \\
(\mathrm{E}, \mathrm{D}, \mathrm{F}, \mathrm{J}) \\
(\mathrm{E}, \mathrm{G}, \mathrm{F}, \mathrm{J})\end{array}$ & $\begin{array}{l}\mathrm{D}=0.3 \\
\mathrm{~F}=0.3 \\
\mathrm{C}=0.2 \\
\mathrm{G}=0.2\end{array}$ \\
\hline$(\mathrm{E}, \mathrm{C})$ & 1 & 2 & $(E, D, C)$ & $\mathrm{D}=1$ \\
\hline
\end{tabular}


Paper-The Dominant Nodes Index in Shortest Paths (DNISP) as a Local Measure of Source Looking for..

\begin{tabular}{|c|c|c|c|c|}
\hline$(\mathrm{E}, \mathrm{F})$ & 2 & 2 & $\begin{array}{l}(\mathrm{E}, \mathrm{G}, \mathrm{F}) \\
(\mathrm{E}, \mathrm{D}, \mathrm{F})\end{array}$ & $\begin{array}{l}\mathrm{G}=0.5 \\
\mathrm{D}=0.5\end{array}$ \\
\hline$(\mathrm{E}, \mathrm{A})$ & 2 & 2 & $\begin{array}{l}(\mathrm{E}, \mathrm{D}, \mathrm{A}) \\
(\mathrm{E}, \mathrm{B}, \mathrm{A})\end{array}$ & $\begin{array}{l}\mathrm{D}=0.5 \\
\mathrm{~B}=0.5\end{array}$ \\
\hline$(\mathrm{G}, \mathrm{I})$ & 1 & 2 & $(\mathrm{G}, \mathrm{H}, \mathrm{I})$ & $\mathrm{H}=1$ \\
\hline$(\mathrm{G}, \mathrm{J})$ & 1 & 2 & $(\mathrm{G}, \mathrm{F}, \mathrm{J})$ & $\mathrm{F}=1$ \\
\hline$(\mathrm{G}, \mathrm{C})$ & 2 & 2 & $\begin{array}{l}(\mathrm{G}, \mathrm{F}, \mathrm{C}) \\
(\mathrm{G}, \mathrm{D}, \mathrm{C})\end{array}$ & $\begin{array}{l}F=0.5 \\
D=0.5\end{array}$ \\
\hline$(\mathrm{G}, \mathrm{A})$ & 3 & 2 & $\begin{array}{l}(\mathrm{G}, \mathrm{F}, \mathrm{A}) \\
(\mathrm{G}, \mathrm{D}, \mathrm{A}) \\
(\mathrm{G}, \mathrm{B}, \mathrm{A})\end{array}$ & $\begin{array}{l}\mathrm{F}=0.33 \\
\mathrm{D}=0.33 \\
\mathrm{~B}=0.33\end{array}$ \\
\hline$(\mathrm{D}, \mathrm{H})$ & 2 & 2 & $\begin{array}{l}(\mathrm{D}, \mathrm{G}, \mathrm{H}) \\
(\mathrm{D}, \mathrm{F}, \mathrm{H}) \\
\end{array}$ & $\begin{array}{l}\mathrm{G}=0.5 \\
\mathrm{~F}=0.5\end{array}$ \\
\hline$(\mathrm{D}, \mathrm{I})$ & 4 & 3 & $\begin{array}{c}(\mathrm{D}, \mathrm{G}, \mathrm{H}, \mathrm{I}) \\
(\mathrm{D}, \mathrm{F}, \mathrm{J}, \mathrm{I}) \\
(\mathrm{D}, \mathrm{F}, \mathrm{H}, \mathrm{I}) \\
(\mathrm{D}, \mathrm{C}, \mathrm{J}, \mathrm{I})\end{array}$ & $\begin{array}{c}\mathrm{G}=0.15 \\
\mathrm{C}=0.15 \\
\mathrm{~F}=0.23 \\
\mathrm{H}=0.23 \\
\mathrm{~J}=0.23\end{array}$ \\
\hline$(\mathrm{D}, \mathrm{J})$ & 2 & 2 & $\begin{array}{l}(\mathrm{D}, \mathrm{C}, \mathrm{J}) \\
(\mathrm{D}, \mathrm{F}, \mathrm{J})\end{array}$ & $\begin{array}{l}\mathrm{C}=0.5 \\
\mathrm{~F}=0.5\end{array}$ \\
\hline$(\mathrm{H}, \mathrm{J})$ & 2 & 2 & $\begin{array}{l}(\mathrm{H}, \mathrm{I}, \mathrm{J}) \\
(\mathrm{H}, \mathrm{F}, \mathrm{J}) \\
\end{array}$ & $\begin{array}{l}\mathrm{I}=0.5 \\
\mathrm{~F}=0.5\end{array}$ \\
\hline$(\mathrm{H}, \mathrm{C})$ & 1 & 2 & $(\mathrm{H}, \mathrm{F}, \mathrm{C})$ & $\mathrm{F}=1$ \\
\hline$(\mathrm{H}, \mathrm{A})$ & 1 & 2 & $(\mathrm{H}, \mathrm{F}, \mathrm{A})$ & $\mathrm{F}=1$ \\
\hline$(\mathrm{H}, \mathrm{D})$ & 2 & 2 & $\begin{array}{l}(\mathrm{H}, \mathrm{F}, \mathrm{D}) \\
(\mathrm{H}, \mathrm{G}, \mathrm{D})\end{array}$ & $\begin{array}{l}F=0.5 \\
G=0.5\end{array}$ \\
\hline$(\mathrm{H}, \mathrm{B})$ & 1 & 2 & $(\mathrm{H}, \mathrm{G}, \mathrm{B})$ & $\mathrm{G}=1$ \\
\hline$(\mathrm{H}, \mathrm{E})$ & 1 & 2 & $(\mathrm{H}, \mathrm{G}, \mathrm{E})$ & $\mathrm{G}=1$ \\
\hline$(\mathrm{I}, \mathrm{C})$ & 1 & 2 & $(\mathrm{I}, \mathrm{J}, \mathrm{C})$ & $\mathrm{J}=1$ \\
\hline$(\mathrm{I}, \mathrm{F})$ & 2 & 2 & $\begin{array}{c}(\mathrm{I}, \mathrm{J}, \mathrm{F}) \\
(\mathrm{I}, \mathrm{H}, \mathrm{F})\end{array}$ & $\begin{array}{c}\mathrm{J}=0.5 \\
\mathrm{H}=0.5\end{array}$ \\
\hline$(\mathrm{I}, \mathrm{A})$ & 2 & 3 & $\begin{array}{c}(\mathrm{I}, \mathrm{H}, \mathrm{F}, \mathrm{A}) \\
(\mathrm{I}, \mathrm{J}, \mathrm{C}, \mathrm{A})\end{array}$ & $\begin{array}{l}\mathrm{J}=0.25 \\
\mathrm{~F}=0.25 \\
\mathrm{H}=0.25 \\
\mathrm{C}=0.25\end{array}$ \\
\hline$(\mathrm{I}, \mathrm{D})$ & 4 & 3 & $\begin{array}{c}(\mathrm{I}, \mathrm{H}, \mathrm{G}, \mathrm{D}) \\
(\mathrm{I}, \mathrm{H}, \mathrm{F}, \mathrm{D}) \\
(\mathrm{I}, \mathrm{J}, \mathrm{F}, \mathrm{D}) \\
(\mathrm{I}, \mathrm{J}, \mathrm{C}, \mathrm{D})\end{array}$ & $\begin{array}{l}\mathrm{H}=0.23 \\
\mathrm{G}=0.15 \\
\mathrm{~F}=0.23 \\
\mathrm{~J}=0.23 \\
\mathrm{C}=0.15\end{array}$ \\
\hline$(\mathrm{I}, \mathrm{G})$ & 1 & 2 & $(\mathrm{I}, \mathrm{H}, \mathrm{G})$ & $\mathrm{H}=1$ \\
\hline$(\mathrm{I}, \mathrm{B})$ & 1 & 3 & $(\mathrm{I}, \mathrm{H}, \mathrm{G}, \mathrm{B})$ & $\begin{array}{l}\mathrm{H}=0.5 \\
\mathrm{G}=0.5\end{array}$ \\
\hline$(\mathrm{I}, \mathrm{E})$ & 1 & 3 & $(\mathrm{I}, \mathrm{H}, \mathrm{G}, \mathrm{E})$ & $\begin{array}{l}\mathrm{H}=0.5 \\
\mathrm{G}=0.5\end{array}$ \\
\hline$(\mathrm{J}, \mathrm{H})$ & 2 & 2 & $\begin{array}{l}(\mathrm{J}, \mathrm{I}, \mathrm{H}) \\
(\mathrm{J}, \mathrm{F}, \mathrm{H})\end{array}$ & $\begin{array}{l}\mathrm{I}=0.5 \\
\mathrm{~F}=0.5\end{array}$ \\
\hline$(\mathrm{J}, \mathrm{G})$ & 1 & 2 & $(\mathrm{~J}, \mathrm{~F}, \mathrm{G})$ & $\mathrm{F}=1$ \\
\hline$(\mathrm{J}, \mathrm{E})$ & 2 & 3 & $\begin{array}{l}(\mathrm{J}, \mathrm{F}, \mathrm{G}, \mathrm{E}) \\
(\mathrm{J}, \mathrm{F}, \mathrm{D}, \mathrm{E})\end{array}$ & $\begin{array}{l}\mathrm{F}=0.42 \\
\mathrm{G}=0.28 \\
\mathrm{D}=0.28\end{array}$ \\
\hline$(\mathrm{J}, \mathrm{D})$ & 2 & 2 & $\begin{array}{l}(\mathrm{J}, \mathrm{F}, \mathrm{D}) \\
(\mathrm{J}, \mathrm{C}, \mathrm{D})\end{array}$ & $\begin{array}{l}\mathrm{C}=0.5 \\
\mathrm{~F}=0.5\end{array}$ \\
\hline
\end{tabular}




\begin{tabular}{|c|c|c|c|c|}
\hline$(\mathrm{J}, \mathrm{A})$ & 2 & 2 & $\begin{array}{l}(\mathrm{J}, \mathrm{F}, \mathrm{A}) \\
(\mathrm{J}, \mathrm{C}, \mathrm{A})\end{array}$ & $\begin{array}{l}F=0.5 \\
C=0.5\end{array}$ \\
\hline$(\mathrm{J}, \mathrm{B})$ & 5 & 3 & $\begin{array}{l}(\mathrm{J}, \mathrm{C}, \mathrm{A}, \mathrm{B}) \\
(\mathrm{J}, \mathrm{C}, \mathrm{D}, \mathrm{B}) \\
(\mathrm{J}, \mathrm{F}, \mathrm{D}, \mathrm{B}) \\
(\mathrm{J}, \mathrm{F}, \mathrm{A}, \mathrm{B}) \\
(\mathrm{J}, \mathrm{F}, \mathrm{G}, \mathrm{B})\end{array}$ & $\begin{array}{c}\mathrm{C}=0.2 \\
\mathrm{~A}=0.2 \\
\mathrm{D}=0.2 \\
\mathrm{~F}=0.26 \\
\mathrm{G}=0.13\end{array}$ \\
\hline$(\mathrm{F}, \mathrm{I})$ & 2 & 2 & $\begin{array}{c}(\mathrm{F}, \mathrm{H}, \mathrm{I}) \\
(\mathrm{F}, \mathrm{J}, \mathrm{I})\end{array}$ & $\begin{array}{c}\mathrm{H}=0.5 \\
\mathrm{~J}=0.5\end{array}$ \\
\hline$(\mathrm{F}, \mathrm{E})$ & 2 & 2 & $\begin{array}{l}(\mathrm{F}, \mathrm{G}, \mathrm{E}) \\
(\mathrm{F}, \mathrm{D}, \mathrm{E})\end{array}$ & $\begin{array}{l}G=0.5 \\
D=0.5\end{array}$ \\
\hline$(\mathrm{F}, \mathrm{B})$ & 3 & 2 & $\begin{array}{l}(\mathrm{F}, \mathrm{D}, \mathrm{B}) \\
(\mathrm{F}, \mathrm{G}, \mathrm{B}) \\
(\mathrm{F}, \mathrm{A}, \mathrm{B})\end{array}$ & $\begin{array}{l}\mathrm{D}=0.33 \\
\mathrm{G}=0.33 \\
\mathrm{~A}=0.33\end{array}$ \\
\hline$(\mathrm{C}, \mathrm{I})$ & 1 & 2 & $(\mathrm{C}, \mathrm{J}, \mathrm{I})$ & $\mathrm{J}=1$ \\
\hline$(\mathrm{C}, \mathrm{H})$ & 1 & 2 & $(\mathrm{C}, \mathrm{F}, \mathrm{H})$ & $\mathrm{F}=1$ \\
\hline$(\mathrm{C}, \mathrm{G})$ & 2 & 2 & $\begin{array}{l}(\mathrm{C}, \mathrm{F}, \mathrm{G}) \\
(\mathrm{C}, \mathrm{D}, \mathrm{G})\end{array}$ & $\begin{array}{l}F=0.5 \\
D=0.5\end{array}$ \\
\hline$(\mathrm{C}, \mathrm{E})$ & 1 & 2 & $(\mathrm{C}, \mathrm{D}, \mathrm{E})$ & $\mathrm{D}=1$ \\
\hline$(\mathrm{C}, \mathrm{B})$ & 2 & 2 & $\begin{array}{l}(\mathrm{C}, \mathrm{D}, \mathrm{B}) \\
(\mathrm{C}, \mathrm{A}, \mathrm{B})\end{array}$ & $\begin{array}{l}D=0.5 \\
A=0.5\end{array}$ \\
\hline
\end{tabular}

In the Table 2, each pair of nodes represents a case in itself. The results for applying (DNISP), it can be concluded that the results in Table 3, which shows in general what the controlling nodes are for each node within the Fig 1., as well as the amount of control.

Table 3. Concluded of results

\begin{tabular}{|c|c|c|c|c|c|c|c|c|c|c|}
\hline Nodes & A & B & E & G & D & H & I & J & F & C \\
\hline A & 0 & 0.33 & 0 & 0 & 0.83 & 0.2 & 0 & 0.3 & 2.13 & 0.2 \\
\hline $\mathbf{B}$ & 1.03 & 0 & 0 & 1.96 & 1.03 & 0.5 & 0 & 0 & 0.26 & 0.2 \\
\hline $\mathbf{E}$ & 0 & 0.5 & 0 & 2.2 & 2.3 & 0.5 & 0 & 0 & 0.3 & 0.2 \\
\hline $\mathbf{G}$ & 0 & 0.33 & 0 & 0 & 0.83 & 1 & 0 & 0 & 1.83 & 0 \\
\hline $\mathbf{D}$ & 0 & 0 & 0 & 0.65 & 0 & 0 & 0 & 0.23 & 1.23 & 0.65 \\
\hline $\mathbf{H}$ & 0 & 0 & 0 & 2.5 & 0 & 0 & 0.5 & 0 & 3 & 0 \\
\hline $\mathbf{I}$ & 0 & 0 & 0 & 1.15 & 0 & 0 & 0 & 1.98 & 0.48 & 0.4 \\
\hline $\mathbf{J}$ & 0.2 & 0 & 0 & 0.41 & 0.48 & 0 & 0.5 & 0 & 3.18 & 1.2 \\
\hline $\mathbf{F}$ & 0.33 & 0 & 0 & 0.83 & 0.83 & 0 & 0 & 0.5 & 0 & 0 \\
\hline $\mathbf{C}$ & 0.5 & 0 & 0 & 0 & 2 & 0 & 0 & 1 & 1.5 & 0 \\
\hline
\end{tabular}

\section{$5 \quad$ Results}

For each node there is a different scenario, so when we release data from a specific source node and according to the (DNISP) we will have an accurate visualization of where the data or the ways it will go to the target node. In Table 3. as example F node dominates shortest paths of the A node with a value of 2.13, while shortest paths of B node dominated by $\mathrm{G}$ node with a value of 1.96 . In the same way, we can find the weakest dominant nodes for the shortest paths of each node. The results will reflect 
the application of an algorithm for each case (node). As an example of a node $\mathrm{E}$ from Table 2, it is clearly to see that the D node controls the shortest pathways of the $\mathrm{E}$ node, whereas for a single path between a pair $(\mathrm{E}, \mathrm{I})$ the nodes $\mathrm{G}$ and $\mathrm{H}$ are found to be controlling the single path equally.

In Fig. 2, the results of Table 3 reflect the order of priority of the nodes in the Fig 1. which dominates all shortest path.

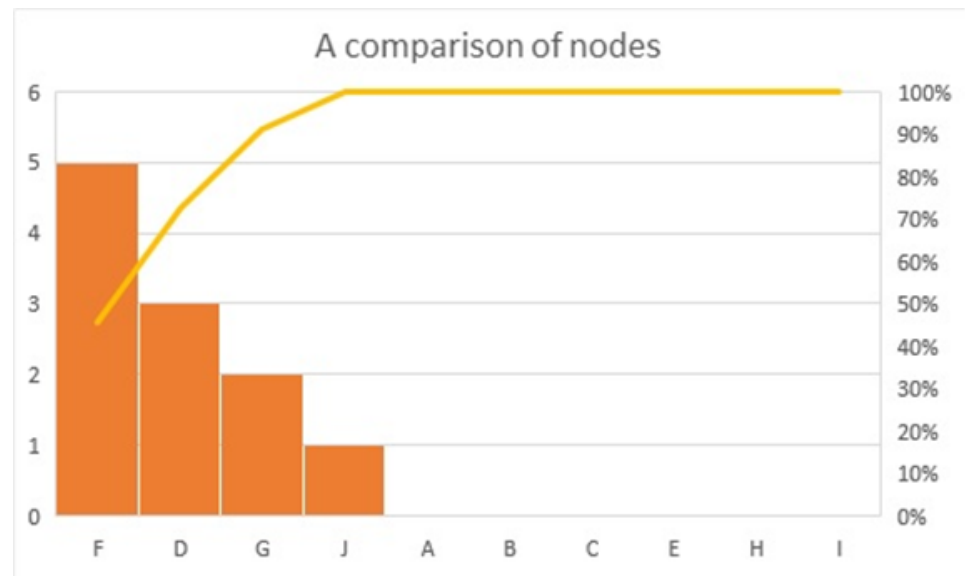

Fig. 2. Comparison of nodes

\section{The Contributions of (DNISP)}

a) Algorithm (DNISP) illustrates the importance of controlling by identifying the ways to transfer information between nodes, assumption that information will take the shortest path (as this is not necessarily always the case).

b) The importance of nodes in short paths between the target and the source is determined by how much value each node gets by applying an algorithm (DNISP).

c) The algorithm can also be exploited in road networks and networks for protein, drug and disease interactions.

d) The control of these nodes in the shortest paths may be significant if the number of shorter paths between the source and the target is limited, but in case of having several shortest paths, there will be more nodes and lower values that control these shortest paths.

e) The algorithm provides an accurate description of the shortest paths between the source and the target.

f) Shortest paths and alternative shortest paths take their significance through the importance and value of the nodes that are distributed by an algorithm (DNISP).

g) The algorithm can be exploited in the process of information diffusion within social networks through knowledge of efficient paths for diffusion and its applications, e-commerce promotion, prevention of rumor, and many others. 
h) The results provided by short paths between pairs can be combined to form an overview of the overall controlling nodes.

i) The algorithm can be the nucleus for creating relevant indicators that are concerned with shorter paths between nodes.

\section{$7 \quad$ References}

[1] A. Pal and S. K. P., Pattern Recognition and Big Data, World Scientific, 2017.

[2] N. Bellomo, A. Bellouquid, L. Gibelli and N. Outada, A quest towards a mathematical theory of living systems., Springer International Publishing., 2017. A. Pal and S. K. P., Pattern Recognition and Big Data, World Scientific, 2017. https://doi.org/10.1007/978-3319-57436-3_5

[3] A. KATHARINA, NETWORK ANALYSIS LITERACY: A Practical Approach to the Analysis of Networks, SPRINGER Verlag GMBH, 2018.

[4] R. K. PM, A. Mohan and K. Srinivasa, Practical Social Network Analysis with Python., Springer International Publishing, 2018.

[5] Hansen, M. A. S. B. Shneiderman and I. Himelboim, Analyzing Social Media Networks with NodeXL: Insights from a Connected World, Morgan Kaufmann, 2019. https://doi.org/ 10.1016/b978-0-12-817756-3.00001-7

[6] M. M. Al-Emran and S. A. Salloum, "Students' attitudes towards the use of mobile technologies in e-evaluation," International Journal of Interactive Mobile Technologies (IJIM), vol. 11, no. 5, pp. 195-202, 2017. https://doi.org/10.3991/ijim.v11i5.6879

[7] J. Leskovec, L. A. Adamic and B. A. Huberman, "The dynamics of viral marketing," ACM Transactions on the Web (TWEB), vol. 1, no. 1, pp. 5-es, 2007.

[8] R. L. Raju and C. R. K. Reddy, "Security Improvisation through Node Trust Prediction Approach in Mobile Ad Hoc Networks," International Journal of Interactive Mobile Technologies (iJIM), vol. 13, no. 9, pp. 40-51, 2019. https://doi.org/10.3991/ijim.v13i09.9329

[9] J. Leskovec and R.Sosič, "Snap: A general-purpose network analysis and graph-mining library," ACM Transactions on Intelligent Systems and Technology (TIST), vol. 8, no. 1, pp. 1-20, 2016. https://doi.org/10.1145/2898361

[10] M. O. Jackson and B. Rogers, "Meeting strangers and friends of friends: How random are social networks?" American Economic Review, vol. 97, no. 3, pp. 890-915, 2007. https:// doi.org/10.1257/aer.97.3.890

[11] H. Lee and I. Sohn, Fundamentals of big data network analysis for research and industry, John Wiley \& Sons, 2015.

[12] P. D. Killworth, C. McCarty, H. R. Bernard and M. House., "The accuracy of small world chains in social networks.," Social networks 28, vol. 1, no. 1, pp. 85-96., (2006). https:// doi.org/10.1016/j.socnet.2005.06.001

[13] R. Pastor-Satorras. and A. Vespignani, "Immunization of complex networks," Physical review E, vol. 65, no. 3, p. 036104, 2002.

[14] D. J. Watts and P. Dodds, "Influentials, networks, and public opinion formation.," Journal of consumer research, vol. 34, no. 4, pp. 441-458, 2007. https://doi.org/10.1086/518527

[15] M. L. Abbott, using statistics in the social and health sciences with SPSS and excel., John Wiley \& Sons, 2016.

[16] N. W. I. Scholtes, R. Pfitzner, A.Garas, C. Tessone and F. Schweitzer, "Causality-driven slow-down and speed-up of diffusion in non-Markovian temporal networks.," Nature communications, vol. 5, no. 1, pp. 1-9, 2014. https://doi.org/10.1038/ncomms6024

[17] W. Chen, Y. Yuan and L. Zhang, "Scalable influence maximization in social networks under the linear threshold model," 2010. https://doi.org/10.1109/icdm.2010.118 
[18] L. Adamic and E. Ada., "How to search a social network," Social networks, vol. 27, no. 3, pp. 187-203, 2005.

[19] E. Bakshy, J. Hofman, W. Mason and D. Watts, "Everyone's an influencer: quantifying influence on twitter.," in Proceedings of the fourth ACM international conference on Web search and data mining, 2011. https://doi.org/10.1145/1935826.1935845

[20] M. E. Newman, H. S. Steven and J. W. Duncan, " Random graphs with arbitrary degree distributions and their applications," Physical review E, vol. 64, no. 2, p. 026118, 2001.

[21] M. Kaya, J. Kawash, S. Khoury and M. Y. Day, Social Network Based Big Data Analysis and Applications., Springer., 2018.

[22] I. G. I. G. Medina and P. A. C. Pereira, "The Importance of Social Media for Commerce. A Case Study in Madeira (Portugal).," International Journal of Interactive Mobile Technologies (iJIM), vol. 6, no. 1, pp. 37-42, 2012. https://doi.org/10.3991/ijim.v6i1.1825

[23] I. H. Li. and H. K. Yee, "Finding galaxy groups in photometric-redshift space: the probability friends-of-friends algorithm," The Astronomical Journal, vol. 135, no. 3, p. 809, 2008. https://doi.org/10.1088/0004-6256/135/3/809

[24] J. M. Kleinberg, "Small-world phenomena and the dynamics of information," 2002

[25] P. Domingos and M. Richardson, "Mining the network value of customers," 2001.

[26] T. Opsahl, F. Agneessens and J. Skvoretz, "Node centrality in weighted networks: Generalizing degree and shortest paths," Social networks, vol. 32, no. 3, pp. 245-251, 2010. https ://doi.org/10.1016/j.socnet.2010.03.006

[27] N. A. and C. S.H., Agent-based modeling and network dynamics, Oxford University Press, 2016.

[28] N. Agarwal, N. Dokoohaki and S. Tokdemir, Emerging Research Challenges and Opportunities in Computational Social Network Analysis and Mining, Springer, 2018

[29] A. Katharina, Network Analysis Literacy: A Practical Approach to the Analysis of Networks, SPRINGER Verlag GMBH, 2018.

[30] R. K. PM, A. Mohan and K. Srinivasa, Practical Social Network Analysis with Python., Springer International Publishing, 2018.

[31] Hansen, M. A. S. B. Shneiderman and I. Himelboim, Analyzing Social Media Networks with NodeXL: Insights from a Connected World, Morgan Kaufmann, 2019. https://doi.org/ $\underline{10.1016 / \mathrm{b} 978-0-12-817756-3.00001-7}$

[32] M. M. Al-Emran and S. A. Salloum, "Students' attitudes towards the use of mobile technologies in e-evaluation," International Journal of Interactive Mobile Technologies (IJIM), vol. 11, no. 5, pp. 195-202, 2017. https://doi.org/10.3991/ijim.v11i5.6879

[33] J. Leskovec, L. A. Adamic and B. A. Huberman, "The dynamics of viral marketing," ACM Transactions on the Web (TWEB), vol. 1, no. 1, pp. 5-es, 2007.

[34] R. L. Raju and C. R. K. Reddy, "Security Improvisation through Node Trust Prediction Approach in Mobile Ad Hoc Networks," International Journal of Interactive Mobile Technologies (iJIM), vol. 13, no. 9, pp. 40-51, 2019. https://doi.org/10.3991/ijim.v13i09.9329

[35] J. Leskovec and R.Sosič, "Snap: A general-purpose network analysis and graph-mining library," ACM Transactions on Intelligent Systems and Technology (TIST), vol. 8, no. 1, pp. 1-20, 2016. https://doi.org/10.1145/2898361

[36] M. O. Jackson and B. Rogers, "Meeting strangers and friends of friends: How random are social networks?" American Economic Review, vol. 97, no. 3, pp. 890-915, 2007. https:// doi.org/10.1257/aer.97.3.890

[37] H. Lee and I. Sohn, Fundamentals of big data network analysis for research and industry, John Wiley \& Sons, 2015.

[38] P. D. Killworth, C. McCarty, H. R. Bernard and M. House., "The accuracy of small world chains in social networks.," Social networks 28, vol. 1, no. 1, pp. 85-96., (2006). https:// doi.org/10.1016/j.socnet.2005.06.001

[39] R. Pastor-Satorras. and A. Vespignani, " Immunization of complex networks," Physical review E, vol. 65, no. 3, p. 036104, 2002. 
[40] D. J. Watts and P. Dodds, "Influentials, networks, and public opinion formation.," Journal of consumer research, vol. 34, no. 4, pp. 441-458, 2007. https://doi.org/10.1086/518527

[41] M. L. Abbott, using statistics in the social and health sciences with SPSS and excel., John Wiley \& Sons, 2016.

[42] N. W. I. Scholtes, R. Pfitzner, A.Garas, C. Tessone and F. Schweitzer, "Causality-driven slow-down and speed-up of diffusion in non-Markovian temporal networks.," Nature communications, vol. 5, no. 1, pp. 1-9, 2014. https://doi.org/10.1038/ncomms6024

[43] W. Chen, Y. Yuan and L. Zhang, "Scalable influence maximization in social networks under the linear threshold model," 2010. https://doi.org/10.1109/icdm.2010.118

[44] L. Adamic and E. Ada., "How to search a social network," Social networks, vol. 27, no. 3, pp. 187-203, 2005.

[45] E. Bakshy, J. Hofman, W. Mason and D. Watts, "Everyone's an influencer: quantifying influence on twitter.," in Proceedings of the fourth ACM international conference on Web search and data mining, 2011. https://doi.org/10.1145/1935826.1935845

[46] M. E. Newman, H. S. Steven and J. W. Duncan, " Random graphs with arbitrary degree distributions and their applications," Physical review E, vol. 64, no. 2, p. 026118, 2001.

[47] M. Kaya, J. Kawash, S. Khoury and M. Y. Day, Social Network Based Big Data Analysis and Applications., Springer., 2018.

[48] I. G. I. G. Medina and P. A. C. Pereira, "The Importance of Social Media for Commerce. A Case Study in Madeira (Portugal).," International Journal of Interactive Mobile Technologies (iJIM), vol. 6, no. 1, pp. 37-42, 2012. https://doi.org/10.3991/ijim.v6i1.1825

[49] I. H. Li. and H. K. Yee, "Finding galaxy groups in photometric-redshift space: the probability friends-of-friends algorithm," The Astronomical Journal, vol. 135, no. 3, p. 809, 2008. https://doi.org/10.1088/0004-6256/135/3/809

[50] J. M. Kleinberg, "Small-world phenomena and the dynamics of information," 2002

[51] P. Domingos and M. Richardson, "Mining the network value of customers," 2001.

[52] T. Opsahl, F. Agneessens and J. Skvoretz, "Node centrality in weighted networks: Generalizing degree and shortest paths," Social networks, vol. 32, no. 3, pp. 245-251, 2010. https ://doi.org/10.1016/j.socnet.2010.03.006

[53] N. A. and C. S.H., Agent-based modeling and network dynamics, Oxford University Press, 2016.

[54] N. Agarwal, N. Dokoohaki and S. Tokdemir, Emerging Research Challenges and Opportunities in Computational Social Network Analysis and Mining, Springer, 2018.

\section{Authors}

Hussein L. Hasan is a Lecturer at Computer Science, University of Babylon/Iraq. He got his B.Sc. in 2001 from University of Babylon /Iraq, M.Sc. in 2010 from Unitar University-Information Technology /Malaysia, Member of ACM, IEEE.

Dr. Salah A. Albermany is a professor at Computer Science, University of Kufa /Iraq. He got his B.Sc. in 1993 from University of Technology/Iraq, M.Sc. in 1996 from Al-Nahrain University/Iraq, Ph.D. in 2004 from Neelain University/Sudan at algorithms and Cryptography, and PostDoc in 2013 from Bedfordshire University/ UK. at Cryptography and Data Communications, Member of ACM, IEEE.

Article submitted 2020-04-22. Resubmitted 2020-08-14. Final acceptance 2020-08-15. Final version published as submitted by the authors. 